\title{
Deep Tissue Invasion
}

National Cancer Institute

\section{Source}

National Cancer Institute. Deep Tissue Invasion. NCI Thesaurus. Code C60830.

Expansion of a malignant cellular infiltrate far downward into the soft tissues. 